\title{
The implementation of public organization communication and its long-term effect on corporate image: A literature review of PT Astra Honda Motor
}

\author{
Pujangga Putra Kartono ${ }^{1, *}$ and Dorien Kartikawangi ${ }^{2}$ \\ 1 Post-Graduate Corporate Management Studies, Faculty of Social and Political Science, \\ Universitas Indonesia, 4 Salemba Raya Street, Kenari, Senen, Central Jakarta, Capital City \\ of Jakarta, Indonesia 10430 \\ 2 Department of Communication Studies, Faculty of Social dan Political Science, \\ Universitas Indonesia \\ *e-mail: pujangga1993@gmail.com
}

\begin{abstract}
PT Astra Honda Motor (AHM) is the top motorcycle production company in Indonesia with total share market above $70 \%$ nationally with distribution volume approximately 6000000 units each year. This growth creates new problems in the society such as increasing number of the road accident, many motorcycle users disobey traffic laws and the increase of underage motorcycle users. This condition is interesting to observe as for how PT AHM do their public organization communication to overcome the rising issues in society. 2 Organization Communication theories are used to strengthen this review, they are 1) public organization communication and 2) organization development and change. These theories become the basis to see how PT AHM internally manage their communication to create an impactful message to their customer and public audience. Based on review to the company, it is found that PT AHM is active and consistent in running their public organization communication. One of their campaign that has been running is "One Heart" or more known as "Satu Hati" campaign. All the campaigns and communications did help PT AHM to avoid accusations of the cause of negative effects of high motorcycle production. Until now, they remain the market leader in national motorcycle market share.
\end{abstract}

\section{Keywords}

Citation: Kartono, P. K. \& Kartikawangi, D. (2018). The implementation of public organization communication and its long-term effect on corporate image. In M. Amini, M. Yusuf, \& V. I. Yulianto. (Eds.), UGM Digital Press Social Sciences and Humanities: Vol. 1. Proceeding of the 2nd International Conference on South East Asia Studies, (pp. 95-105).

Published: October, 2018

communications, impactful message, one heart, organization development, public organization communication

\section{Introduction}

PT Astra Honda Motor (AHM) is a motorcycle production company and also the sole brand right holder of Honda Motorcycle in Indonesia. AHM is a company with 50:50 stock share between Astra International and Honda Motor Company (Astra Honda Motor, 2016). Their relationship that has been going on for a long time have made Honda motorcycle as 
one of the most favorite motorcycle brands in Indonesia. Based on AISI data March 2017, Astra Honda Motor is the market share leader in 2017 with its market share reaching $72 \%$ nationally (Pradopo, 2017, April 16).

AHM success in dominating national motorcycle market share is boosted by their strong brand image among Indonesian people. I believe that AHM dominance in Indonesia is a result of strong and thorough public organization communication that AHM does to their public. Public organization communication has a very important role for AHM in managing their customer's trust and avoiding negative stigma from the audience to particular motorcycle brand.

Building and maintaining a corporate image in the automotive industry (especially motorcycle industry) has its own challenges for the company. There is still a very strong stigma for a motorcycle as the main cause of heavy traffic jam in Indonesia. Low motorcycle price with easy credit payment scheme boost motorcycle sales and keep growing. In fact, the number of total motorcycle distribution in 4 first month of 2017 has reached 2000000 units (Budiawan, 2017, May 18). This number is not surprising, because AHM motorcycle production reaches 5.9 units in 2016 (Astra International, 2016, p. 148).

This huge number had its own consequences for AHM and motorcycle image. News in media often shows careless motorcycle user behavior on the street (e.g. riding in the opposite direction, riding without a helmet, and reckless riding that causes death to the rider). There is also news of many underage riders that still yet to own their driving license. People also mostly discuss motorcycle touring convoy that disturbs public safety and public ordinance.

These issues can turn out to be a big issue if AHM looks away from the reality that is happening in the society. Without proper public organization communication, there could be a new rising stigma that AHM did not care about the environment and only prioritizing their benefit from motorcycle sales. Should that assumption rises, customer and the public audience will start to leave Honda motorcycle and convert to another motorcycle brand that gives more attention to the issues caused by motorcycle growth.

Seeing how AHM still have strong domination in the national motorcycle market, they should have a strong public organization communication to maintain their good image in public's perception. Their public organization communication also proved successful with their positive sales number each year. This journal is written based on these backgrounds to give a better understanding of how AHM public organization communication campaigns help the company in increasing their good image and maintain strong perceptive from public audience.

\section{Findings and Discussions}

\subsection{Public Organization Communication}

One of the main literature that I reviewed in relation to this paper is public organization communication. public organization communication implies of communication form which is done by corporate/organization to either internal or public audience. This communication can be channeled through face to face meetings like a press conference, media question and answer, or town hall session with the corporate audience. Besides face to face meeting, another communication channel can be used via media such as videotape, tv, radio, and many other media.

Zelko and Dance in the book Organizational Communication written by Gerald M. Goldhaber (1993, p. 284) state that internal communication is used as a mean to increase operational efficiency within the organization. Latter this means will be developed between management and corporate human resources, including 1) corporate orientation, 2) safety, 3) workers compensation and benefit, 4) education and improvement, 5) moral improvement, and 6) employee satisfaction. Meanwhile, external communication includes 1) corporate blueprint communication, 2) issue and public opinion communication, and 3) commercial communication. Both these internal and external aspects are divided into each responsible department or divisions within the organization. Zelko and Dance's opinion show that there are differences between public organization communication to internal with public organization communication to external. Seitel in Goldhaber (1993, p. 284) state that public organization communication is a public relations role which is collecting internal and external understanding also receiving corporate blueprint communication. 
Seitel's statement shows that in public organization communication, one organization must first understand their internal needs before they can do proper external public organization communication (Goldhaber, 1993, p. 284). It proves that organization must have the capability to detect and capture their internal organization needs before they create the right external communication message. This is important because an organization consists of departments and divisions that correlate to each other. If a public organization communication message is done without considering all internal aspects, the delivered messages to the external public may be less optimal.

In doing public organization communication, the organization must also consider some contingency factors that could become a basis for them to do proper public organization communication. In Goldhaber (1993, p. 284), these factors are:

1. Economy

2. Technology

3. Legal

4. Social-Political-Cultural

5. Health and environment

6. Internal Activity

These factors must always be considered by the organization to make sure that their public organization communication could cover all the mentioned external factors. Should these factors are not properly attended, then an organization existence may be in danger in the midst of tight economy competition.

Zelko and Dance in Goldhaber (1993, p. 295) state that public organization communication can give advantages to both organizations internal and external audiences. Internally, public organization communication could affect organization efficiency and operations. Externally, public organization communication can increase organization positive image. Public organization communication must be done frequently to create a better long lasting effect. At first, the organization may only be communicating to small groups of audience. With better planning and consistent execution, those small group will reach thousands and even millions of people.

Zelko and Dance in Goldhaber (1993, p. 295) expose the importance of how one organization build their image and in what position they put their organization in the public's perceptive. It also mentions that in the midst of many industry growths, one organization may face difficulty to stand out. Therefore, the right strategic planning is the main key success factor for an organization to obtain a strong positive image and achieve maximum sales result.

The form of public organization communication also varies depending on who to communicate with. Internal public organization communication can be done with the meeting between department heads, meeting with the labor union, employee training, and the other employee. Meanwhile, external public organization communication can be done in a press conference, lobbying the government, commercial advertisement, broadcasted interview, and other media. The many forms of doing public organization communication indicate that one organization must have strong planning in public organization communication so that their message to the public can be conveyed well. Other key elements in effective public organization communication are organization positioning within the public also the frequency of doing public organization communication.

\subsection{Organization Communication and Change Audit Planning}

Next Literature to review is still within Gerald M. Goldhaber book regarding organization communication and change audit planning. One of the discussed subject in this part is about organization development. Organization development is a method which is used to change an organization whether culturally, value, or structure so that the organization can adapt to changes and external dynamics for the years to come.

Gordon Lippit in Goldhaber (1993, p. 322) states that the definition of organizational development is to use knowledge and technique from behavioral science. Organizational development attempt to combine all individual needs to grow and improve organization target and objective to create a more effective organization. Lippit's statement reveals that an organization cannot stay idle to changes and must prepare as best as possible so that the organization, both externally and internally, manage to adapt to all possible changes.

Warren Bennis in Goldhaber (1993, p. 323) states that organizational development is needed by the organization for the present and the future to face major changes in behavior managerial effectively. The above-mentioned changes are:

1. A new concept of human based on their improved knowledge that replaces a simpler man 
2. A new concept of power based on collaboration and reason that replaces the concept of power based on extortion and threats

3. A new concept of organization based on a humanitarian-democracy approach that replaces mechanic bureaucracy system.

On creating and planning, an organization usually used consultant services that are ready to help develop new values within the organization although there is some company that manages internal consultant for changes. Even so, an organization must have a full-fledged plan and they cannot start changes spontaneously before starting doing development. First, an organization must be able to analyze what are the main issues, both internally and externally, that should become the first priority to complete. An organization also think who will initiate and lead the development process. Besides that, an organization needs to have a clear mapping of their top performing employee and see their way to work, so they can become the benchmark for other employees.

Communication consultant is divided into 3 main models. The first model is the purchase model. This model illustrates a condition of which the organization inquires their needs to consultant after diagnosing a trouble in the organization body. After finding the core issues, an organization meets the consultant to buy needed solution based on their trouble. After the consultant gives the solution, the organization will end the project. Basically, in this model, all existing troubles are analyzed by the organization themselves and the consultant only gives the solution. Schein in Goldhaber (1993, p. 326) state that the success of this model is very depending on how accurate the clients (organization, department, manager) in diagnosing their own needs and communicating it to the consultant, also figuring out the consequences of the intervention and recommendation given by the consultant.

The second model in communication consultancy is the Doctor-Patient Model. In this model, the client approaches the communication consultant without knowing for sure of what is the organization problems. In this model, the consultant has a massive role in finding out clearly about the main issues in the organization. Chaplan in Goldhaber (1993, p. 326) states that the consultant main objective of this model is to fix and improve the way their clients communicate. Therefore, a consultant has a basic role to make an assessment of their client's condition so they can find solutions or new communication method that can be used by their clients. This model demands that consultant do full communication audit in the organization, but this model also have a risk for failure if the consultant cannot figure out the problems in the organization, so they will not clearly describe the organization problems.

The third model is Process Model. This model explains an organization problem solving from both the organization and the consultant. They work together starting from the initial process until the problems are solved. In this model, both side equally diagnoses the organization condition and do an intervention. Both sides could also end their working relations if the problems are already solved. This model assumed that clients don't know about the existing problems and don't understand the available help that exists, but they realize that it is better to solve their problem themselves. A consultant is assumed willingly to collaborate with their client, give alternate solutions, and is an expert in problem diagnose. This model is more on the consultant role to guide their client in handling problems so that clients will have sufficient knowledge in solving their own problems in the future without using consultant services.

After a contract between the clients and the consultant are made, then the problem diagnosis phase begins. Weisberd in Goldhaber (1993, p. 334) reveals that there are 6 main categories to diagnose by the consultant. These 6 categories are purposes, structure, leadership, relationships, helpful mechanisms, and rewards. After all these 6 categories are diagnosed, then the consultant can start creating first steps of necessary solutions to take.

During this diagnosis steps, intervention process can already be started by the consultant. As stated by Turner in Goldhaber (1993, p. 335) 8 fundamental objectives of a consultant are to:

1. Give information to clients

2. Solve client's problems

3. Create diagnosis that may have to make organization redefine the problems they face

4. Creating recommendation based on the diagnosis result

5. Help do implementation on the given recommendation

6. Build a consensus and commitment for improvement action

7. Facilitating learning curve for the client, how to manage their own problems in the future

8. Permanently increasing organization effectiveness 


\section{Research Methods}

This review is mainly based on qualitative approach. The review is based on selected communication campaigns that AHM has done to the public. The main review focus on AHM newly launched communication campaign such as their newest safety riding campaign \#Cari_Aman and their current long-running communication campaign "One Heart" (or Satu Hati in Bahasa). The review then will correlate to a case analysis regarding their connection to AHM internal process of preparing their communication campaigns. This review will see how AHM manage their communication campaign and their steps in reaching maximum communication campaign result. The review also includes AHM public organization communication that has established as the yearly event and already well known by public audiences.

The review then will be connected to the literature review on the previous subchapter. The latter review becomes basic assumptions and proves if AHM public organization communication able to change customer and public perception of issues that are caused by motorcycle industry. The other possibility, it can prove AHM public organization communication did not reach optimal results.

\subsection{PT Astra Honda Motor Internal Public Organization Communication Analysis}

PT AHM is the top market leader in national motorcycle market with market share reaching $72 \%$ (Pradopo, 2017, April 16). AHM also have high production yearly volume, reaching up to 6000000 unit of motorcycle each year. AHM big production volume capability comes from the various manufacturing factories that they own. In total, AHM own 5 manufacturing factories located in Jakarta (Sunter and Pegangsaan), Cikarang, and 2 newest factories in Karawang. These 5 factories are also completed with Parts Centre as AHM spare part production center and Production Quality Engineering site to test motorcycle engine and capability.

AHM has estimated 25000 employees in total to support the operations of all their factories and achieving high production volume target. These employees are a mix of factory workers and office workers. The huge amount of organization employees makes AHM have a diverse and large organizational structure. This affects the communication network and method in the company. AHM divide their organization into 4 different directorates. The first is Production Engineering and Procurement Directorate which mainly responsible for the motorcycle production from the factory standard operation procedure, production new technology, spare part, and supply procurement to the supplier. The Second is Finance Directorate which manages all finance and accounting business within the company including expenses policies and budget diversification. The third is HR (Human Resources), GA (General Affairs), IT (Information Technology) Directorate which manages all human resources problems, office and factories general needs, and information technology support. The fourth is the Marketing Directorate which responsible for ensuring optimal sales, marketing, service effort, maximum sales, and satisfaction achievement. The main focus of this article is the fourth directorate. 


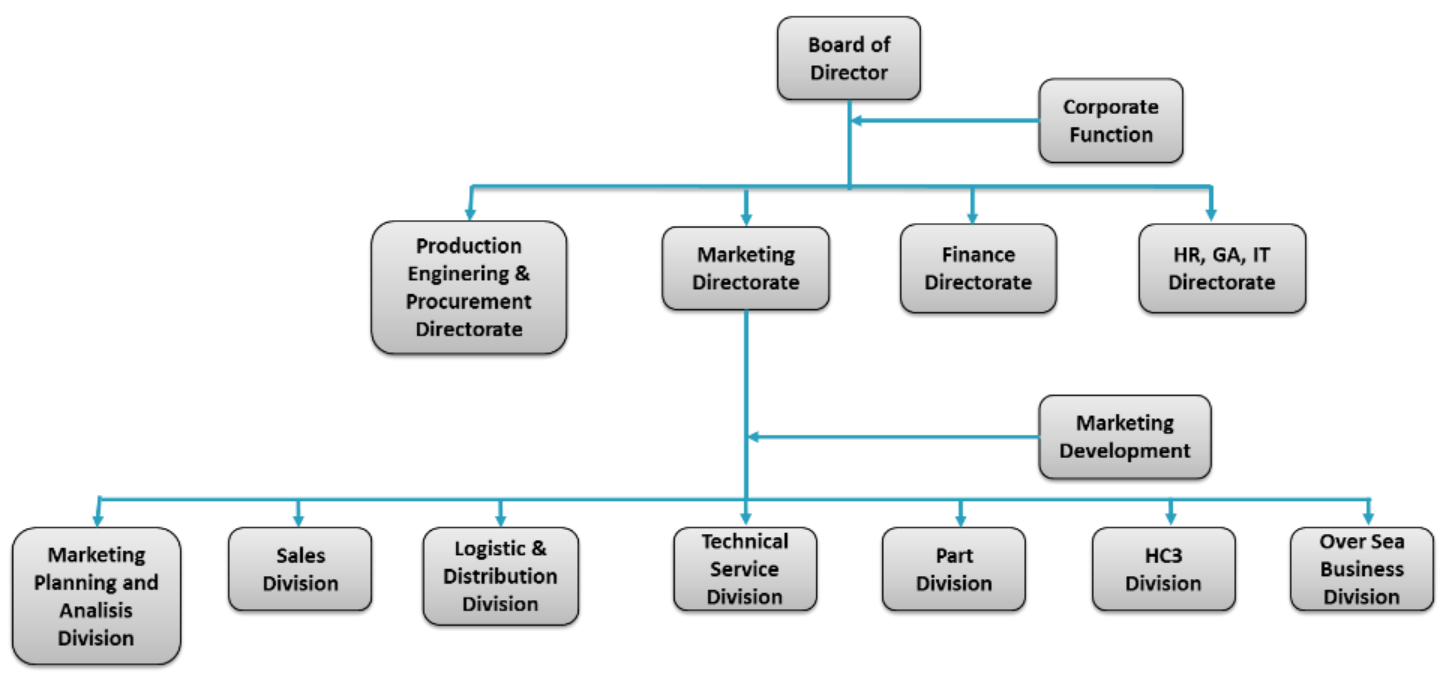

Fig.1 Astra Honda Motor Organization Structure

In the Fig. 1, we can see that Marketing Directorate is split again into 7 divisions such as Marketing Planning and Analysis Division, Sales Division, Logistic and Distribution Division, Technical Service Division, Part Division, Honda Customer Care Center Division, and Oversea Business Division. All those divisions are supported by a corporate function that includes in it is the organization public relations and communication officers. Each of the divisions above is split again into several departments, of which each department have a role in establishing public organization communication to the public. One of the divisions that are vital in developing public organization communication is Marketing Planning Analysis Division. This Division itself consists of 8 different departments:

1. Product Management Department

This department manages all Honda motorcycle product lineup preparation. Collaborating with Honda Japan and other Honda affiliations, this department is responsible in managing the flow of Honda new lineups when to launch the new product, what are the colors, what are their apparel and accessories, when will it be distributed, etc. This department usually becomes the project leader of upcoming new Honda Motorcycle product.

2. Consumer Insight Department

This department main task is to do survey toward Honda customer and competitor customer. The survey done varies on regarding the new product, campaign, customer satisfaction, also surveying Honda competitor's customer.

3. Safety Riding and Motorsport Department

This department heavily focuses on motorsport activities and creating campaigns regarding safety riding to all Honda network and customer.

4. Network Physical Department

This department manages standardization of Honda network throughout Indonesia. The focus on how the Dealer network look and design that must follow AHM standards.

5. Advertising Department

This department mainly in charge of preparing all promotion material and advertising campaign for Honda motorcycle products and campaigns.

6. Digital Advertising Department

This department has the same role as advertising department but their main domain is on the digital network.

7. Brand Activation Department

This department is responsible for increasing brand and product image awareness through the event and other offline activities, also support all corporate events preparation.

8. Community Development Department

This department is responsible for managing all Honda community clubs and creating various activities to support the communities existence and growth.

All those mentioned departments have vital parts in developing Astra Honda Motor public organization communication to their vast audience. But, before AHM do their public organization communication to the 
public they must first get their perception align internally. As mentioned in Goldhaber (1993, p. 13), an organization must know what their internal audience want first before executing public organization communication to external. In AHM, before facing new production year, all organization management members join together in planning cycle phase. This planning cycle is separated into the different level from level 1 planning to level 4 planning which will become the final blueprint program for the coming years. The planning phase starts from department levels and each department will join together for division level planning. After several revisions and planning, the approved division level planning will be brought to directorate level. Here, all divisions under marketing directorate will present their division plan to the Directors. After all is final, all Directors join in shareholder meeting to finalize the yearly plan for all corporate body.

AHM internal coordination is not only through planning cycle. To help monitor planned program, AHM internal have monthly PDCA (Plan, Do, Check, Action) meeting that is separated into several levels same as the planning cycle. This PDCA started at the department level and will be continued to directorate level. During this PDCA process, all management member start from department level will join together to discuss monthly activities that are currently running. With this PDCA meeting, all department and division related to the organization will always know other departments working program. So, they can coordinate to collaborate all related program work so that it will stay inline. With this process, one point mentioned in Goldhaber (1993, p. 13) is proven because of AHM fully aware of the importance of internal coordination to align their perception in creating work program.

Frequent coordination within the organization internal body is one indicator that public organization communication to the internal audience by AHM has become their key success in generating impactful public organization communication to their external public. This proves one factor of public organization communication the internal activity factor. Large human resources number inside the organization does not stop AHM in generating well coordinated internal communication system. The next subchapter will focus on how AHM manage their public organization communication to their external audience.

\subsection{Astra Honda Motor External Public Organization Communication}

As previously explained in the introduction, AHM problem is no longer about dominating the national motorcycle market share. They also try change negative public perception toward the growth of motorcycle volume in the streets and the negative effect caused by it. As explained in public organization communication literature review, one of the factors that can push the organization to do external public organization is factory environment factor.

AHM actively commence public organization communication campaign both for commercial and social purposes. In this case, I will highlight AHM public organization communication that fulfills the social purposes. One of the more famous AHM campaigns is "One Heart" campaign also well known as "Satu Hati". This campaign is launched in 2010 (Suryanto, 2010, August 10). "One Heart" is a value that the organization tries to develop as a manifestation that AHM always considers customer needs to produce a motorcycle that resembles their customer's dream. At the beginning of the campaign, "One Heart" is introduced as TV Commercial to the public. AHM create a special theme jingle and video advertisement with their current brand ambassador (Agnes Monica and Nidji).

In creating their campaign, AHM uses the third communication consultancy in the process model. AHM uses the help of communication and marketing consultant and together initiate the start of their communication campaign. AHM uses the insight and knowledge of their partners to get the best direction for all their communication campaign. This process is always repeated in the forthcoming AHM communication strategy. However, their main use of communication consultant is not only for the fresh ideas, but also to support them in implementing the campaign like creating promotion material, a photo shoot for the promotion material, placement of promotion material, and creating a special event to boost awareness and participation of the communication campaign.

In "One Heart" campaign, AHM starts to show their commitment to the value by sharing and spreading this campaign to all their network and to their customer. Internally, AHM implements "One Heart" campaign as the main organization value. Within "One Heart" they create 4 main working values such as Respecting Others, Responsible, Integrity, and Innovation. These values are placed in every supporting element in the organization and implemented by placing the value card in all employee ID card and through all internal communication network. AHM also oblige their Main Dealer, Dealer, and Service Station to follow basic protocols of mentioning "Salam Satu Hati" every time they welcome their guest in dealers, 
when they answer telephone calls, even when they answer e-mail. This cause help customer to be more aware of the campaign and have a better understanding of this campaign.

Externally, AHM always put their One Heart brand in all their promotional material. All promotion material (TVC, banner, billboard, product ad., flyer, etc.) have to include "One Heart" logo beside their wellknown wing mark. "One Heart" jingle also becomes a must to play in every AHM and their Main Dealers activation event. Besides that, AHM also supports Honda Moto GP racing team by placing "One Heart" and "Satu Hati" brand on the racers racing suit (Munikartono, 2012, February 22). This logo placement on Honda Moto GP racing suit caught public attention and makes them more aware of the campaign. AHM also actively invite Marc Marquez and Dani Pedrosa to Indonesia to do meet and greet with their fans. Alongside it, they try to show how Honda "One Heart" help them achieve their success.

AHM strong effort in communication "One Heart" and "Satu Hati", related to public organization communication theory by Goldhaber $(1993$, p. 13) can be seen as the organization effort in creating different positioning than any other motorcycle manufacturer in Indonesia. "One Heart" and "Satu Hati" started as a promotional communication campaign but has established to become better known as Honda Brand value. AHM manage to position themselves as a motorcycle manufacturer that help customers in achieving their dream with "One Heart" value. A value shows that AHM listens to their customers demand and implement their demand for a reliable product and top notch customer care services.

Honda motor competitor in Indonesia such as Yamaha also has the main slogan for their product "Semakin di Depan". This slogan has very clear differences with "One Heart" value. Yamaha's "Semakin di Depan" focuses on their product. Yamaha wants to show that their product is more advanced and have better performance than their other competitors. Meanwhile, "One Heart" slogan has a more flexible meaning and can be correlated to all AHM activities. AHM consistently use "One Heart" on all their public organization communication and it is not limited to their product but also their services.

AHM further boost "One Heart" value by becoming the main title sponsor for high school national basketball competition DBL (Developmental Basketball League). By becoming main title sponsor, AHM has the right to use their brand name in the event title. This collaboration helped Honda to promote their "One Heart" value to Honda DBL audience, who mostly are entry level customer on a motorcycle market (Basudewa, 2017, July 15). AHM create strong "One Heart" branding throughout the venue and manage to influence students in more acknowledging "One Heart" value.

AHM "One Heart" campaign is a public organization communication method that AHM does to divert customer attention to negative issues regarding motorcycle industry. However, this campaign is not the only arsenal in AHM sleeve. One Heart campaign now has become an umbrella for all other AHM public organization communication. Their goals to help achieve customer dream is supported by another public organization communication campaign to strengthen "One Heart" value and increase the positive public perception of AHM.

On 29th March 2017, AHM has launched another public organization communication campaign meant for social purposes. This campaign is related to safe riding issues that remains one of the hottest issues in the motorcycle. This campaign is called \#Cari_Aman. Interestingly, AHM launched this campaign together with new product launching All New Honda Scoopy. AHM want to use the momentum of new product launching so that their new safety riding campaign also got maximum attention from media that cover the event.

To put it simply, \#Cari_Aman campaign focus is to change motorcycle rider habit on the street. The first phase of this campaign is reminding motorcycle rider to use riding jacket and click their helmet properly before taking a ride. Safety riding itself is not a new concern for AHM. Before this campaign was launched, $\mathrm{AHM}$ and their Main Dealers already have 5 safety riding center which opens for the public to learn how to ride a motorcycle safely and in a proper manner. This safety riding center is active in giving safety riding education to students. They are located in 5 major cities in Indonesia such as Surabaya, Banten, Tangerang, Jambi, and Yogyakarta (Fitriani, 2017, May 16).

However, according to AHM internal survey, safety riding awareness keep decreasing from previous years. In 2014, safety riding awareness number reaches $49 \%$, while in 2015 it decreases to $41 \%$ (Nugroho, 2016). This decrease in safety riding awareness pushes AHM to create new safety riding communication campaign through \#Cari_Aman. To create the right message, AHM does organizational communication change. Goldhaber in Organizational Communication (1993, p. 320) state that an organization will use the help of consultant service to achieve maximum communication change.

In developing \#Cari_Aman campaign, AHM uses advertising agency service to help create \#Cari_Aman content. In creating this campaign, agency role is not merely creating good communication campaign content but also create the right communication message to be released during press conference session 
on its launching day. AHM collaboration system with their agency is using Process Model collaboration, which according to Goldhaber $(1993$, p. 294) is a form of collaboration where both organization and consultants do an intervention to each other until they reach a clear agreement on improvement point. The results from both side intervention create several decisions that reflect the organization needs.

\#Cari_Aman campaign is more positioned to the active and dynamic youngster. According to one of motomaxx.id articles, the terms "Cari Aman" itself is commonly used the term by Indonesian youth to refer as finding safety in facing problems that may happen to them (Hamzah, 2017, March 31). The use of the hashtag (\#) in front of the word Cari Aman also indicates that this campaign is aimed at youth active in social media. It may be too soon to evaluate how far have this campaign achieved in changing rider habit to be safer in riding their motorcycle. Through this campaign, AHM has made different positioning from their competitor, so their campaign could become the pioneer and icon in safe riding.

If AHM manages to run this campaign consistently, then it is very possible for this campaign to reach the same success "One Heart" campaign had achieved. Currently, according to an article from tribunkaltim.co, one of the positive perceptions from Honda customer is that their product is the most fuel efficient (Dwinanto, 2018, February 13). In creating more campaign related to safety riding, another positive perception can be created. By using "One Heart" campaign, they want to show that they fully support their customer in achieving their dream. Meanwhile, \#Cari_Aman campaign is created to show that AHM is also concerned about safe riding in Indonesia and hopefully can help create a better understanding of how important it is to stay safe on the road.

\section{Discussions}

AHM case review has shown that AHM has more advanced and different public organization communication compared to their competitor in the same industry. A unique approach in their campaign has made AHM public organization communication campaign one step ahead of their competitors. AHM communication campaign message that focuses on issues other than product selling have given them more added value in the customer perceptive. "One Heart" and \#Cari_Aman campaign that focuses more on customer value can be used as a new persuasive tool to their customer. Besides that, these campaigns show that AHM gives total attention to give better service to their customer and stronger attention to motorcycle riding safety issues.

This assumption is related to journal research by Krishna S. Dhir from Berry School of Business with the title Corporate Communication through Nonviolent Rhetoric: Environmental, Agency and Methodological Prerequisites. In this journal, Dhir states that stakeholder can be persuaded with more persuasive, attractive, and entertaining approach (Dhir 2006, p. 263). This is also relevant to The Nonviolent Rhetoric theory that implies if communication to stakeholder must be able to increase awareness, educate, train, also contribute to stakeholder prosperity.

The review of that theory in Krishna S. Dhir (2006, p. 253) journal aligns with AHM \#Cari_Aman communication campaign. Through \#Cari_Aman, AHM wants their stakeholder to have new and more fun perceptive regarding the importance of safe riding. One Heart campaign that has been running for the past 7 years also give a lot of additional values toward the public perception values to Honda motorcycle.

AHM successful public organization communication can be achieved through strong and well structured internal communication within the organization. Yearly planning followed by monthly review through various level help the internal communication flow to get better. AHM internal communication that demands all employee to stay connected to each other, help AHM to avoid communication disturbance within the organization. In a journal written by Hassan Abu Bakar and Che Su Mustaffa (2012, p. 104) titled Organizational Communication in Malaysia Organizations: Incorporating Cultural Values in Communication Scale reveals that good organization communication construction can help increase work satisfaction. This satisfaction is supported by many factors such as good communication flow, communication climate, message characteristic, communication structure, group bond, and respect each other. Strong communication in AHM internal can be a plus factor for the organization in managing optimal external public organization communication campaign.

AHM public organization communication also calculates the factors mentioned in literature review subchapter. Economically, AHM has no problem in creating public organization communication since they already dominate the national market. Legally, what AHM do did not oppose any existing laws while in fact, 
their \#Cari_Aman campaign may help the government and police in regulating rules they created. Sociopolitico-cultural factor defined by AHM in their "One Heart" and \#Cari_Aman campaign, where AHM consider social phenomena happening in society and create a program to use the situation to their advantage.

\section{Conclusions}

PT Astra Honda Motor as the national leading market leader already have good public organization communication that not only focusing on increasing sales but also touching emotional side of their customers. AHM strategy in creating social purpose of public organization communication can be seen as a way to create more positive public perception toward motorcycle industry and forget about the negative stigma to motorcycle riders. Their campaign shows that even though AHM has big production volume, they still have a responsibility for creating safer riding environment for the public. The campaign itself is pretty simple but with more intensive communication, AHM can become the pioneer in introducing safety riding to the audience. Besides that, they may be regarded as the first motorcycle manufacturer to help create better riding environment for the people.

Honda has done a lot of public organization communication campaign and it may be better if the organization can stay focus on the main purposes of their communication campaign. The use of "One Heart" as the communication campaign umbrella completed with other communication campaign makes Honda have a vast communication network and will further increase AHM positive image.

Acknowledgments to Dorien Kartikawangi for the support in this research, PT Astra Honda Motor for sharing their organization data for the good of the research, and to Mei Karima and Kinara, my loving family for their continuous support

\section{References}

Astra Honda Motor. (2016). Corporate profile. Astra-Honda. [In Bahasa Indonesia]. Retrieved from https://www.astra-honda.com/corporate

Astra International. (2016). 2016 Annual report. Astra-Honda. [In Bahasa Indonesia]. Retrieved from https://www.astra.co.id/Public/29\%20Mar\%202017/AstraInternational_AR_2016.pdf

Bakar, H. A., \& Mustaffa, C. S. (2012). Organizational communications in Malaysia Organizations: Incorporating cultural values in communication scale. Corporate Communications: An International Journal, 18(1), 87-109. doi:10.1108/13563281311294146

Basudewa, D. (2017, July 15). Astra Honda Motor dukung generasi muda berbakat. [Astra Honda Motor supports young talented generation]. Otospirit. [In Bahasa Indonesia]. Retrieved from https://www.otospirit.com/autos/astra-honda-motor-dukung-generasi-muda-berbakat/25733

Budiawan, A. H. (2017, Mei 18). Distribusi motor Januari-April 2017 nyaris sentuh 2 juta unit [Motorcycle distribution from January-April 2017 nearly reached 2 million unit]. Metrotvnews.com. [In Bahasa Indonesia]. Retrieved from http://m.metrotvnews.com/otomotif/motor/PNg4e6Rb-distribusi-motorjanuari-april-2017-nyaris-sentuh-2-juta-unit

Dhir, K. S. (2006). Corporate communication through nonviolent rhetoric: Environmental, agency and methodological prerequisites. Corporate Communications: An International Journal, 11(3), 249-266.

Dwinanto, R. (2018, February 13). Motor irit BBM jadi pilihan konsumen, ini motor paling dipilih masyarakat Samarinda. [Fuel efficient motorcycle becomes consumer choice, there is the most selected motorcycle by people in Samarinda]. TribunKaltim.co. [In Bahasa Indonesia]. Retrieved from http://kaltim.tribunnews.com/2018/02/13/motor-irit-bbm-jadi-pilihan-konsumen-ini-motor-palingdipilih-masyarakat-samarinda 
Fitriani, E. (2017, May 16). AHM gelar kompetisi keselamatan berkendara bagi instruktur. [AHM held safety riding competition for instructors]. Beritasatu.com. [In Bahasa Indonesia]. Retrieved from http://www.beritasatu.com/ekonomi/431049-ahm-gelar-kompetisi-keselamatan-berkendara-bagiinstruktur.html

Goldhaber, G. M. (1993). Organizational communication, 6th edition. New York, USA: SAGE Publication Inc.

Hamzah, A. (2017, March 31). Tagline \#Cari_Aman, Honda rangsang generasi muda cintai safety riding [Tagline \#Cari_Aman, Honda invite young generation to love safety riding]. Motomaxx. [In Bahasa Indonesia]. Retrieved from https://motomaxx.id/2017/03/31/tagline-cari_aman-honda-rangsanggenerasi-muda-cintai-safety-riding/

Munikartono, D. (2018, February 22). Makna tagline "Satu Hati” bagi Marquez-Pedrosa [Meaning of "Satu Hati” tagline to Marquez-Pedrosa). Motorsport.com. [In Bahasa Indonesia]. Retrieved from https://id.motorsport.com/motogp/news/makna-tagline-satu-hati-marc-marquez-dani-pedrosamotogp-1007510/

Nugroho, D. A. S. (2016). Safety riding department presentation, [PowerPoint slide). [In Bahasa Indonesia]. [Online unpublished]

Pradopo, D. (2017, April 16). Penjualan motor AISI Maret 2017, Honda naik Yamaha terdongkrak Aerox [AISI motorcycle sales in March 2017, Honda increased, Yamaha boosted by Aerox]. Otomotifnet.com. [In Bahasa Indonesia]. Retrieved from https://otomotifnet.gridoto.com/read/02190304/penjualanmotor-aisi-maret-2017-honda-naik-yamaha-terdongkrak-aerox-

Suryanto (ed.). (2010, August 9). AHM umumkan tagline baru "One Heart". [AHM announces new "One Heart" tagline]. Antaranews.com. [In Bahasa Indonesia]. Retrieved from

http://www.antaranews.com/berita/215492/ahm-umukan-tagline-baru-one-heart 